\title{
Mechanical zonation of rock properties and the development of fluid migration pathways: implications for enhanced geothermal systems in sedimentary-hosted geothermal reservoirs
}

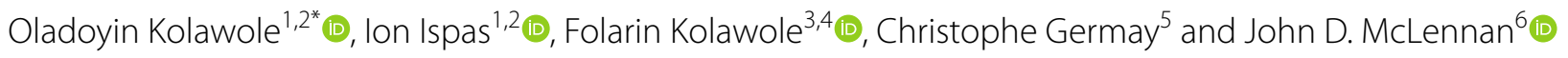

*Correspondence:

doyin.kolawole@ttu.edu

${ }^{1}$ Rock Mechanics Laboratory, Texas Tech University, 101

Terry Fuller Petroleum Engineering Research

Building, Lubbock, TX, USA

Full list of author information is available at the end of the article

\begin{abstract}
Oil and gas operations in sedimentary basins have revealed the occurrence of significant temperature anomalies at depth, raising the possibility of major geothermal resource potential in the sedimentary sequences. The efficient development of such a resource may require enhancement by hydraulic stimulation. However, effective stimulation relies on an initial assessment of in situ mechanical properties and a model of the rock response. Here, we examine the distribution of mechanical properties (unconfined compressive strength, UCS; ultrasonic velocity-derived Poisson ratio, v; and, scratch toughness, $K_{\mathrm{s}}$ ) along the cored interval of a sedimentary formation with a known low-to-medium temperature geothermal anomaly in the Permian Basin, U.S. Our results reveal the presence of mechanical stratigraphy along the core, demonstrated by the alternation of distinct soft-hard (i.e.,less stiff-to-stiff) mechanical zone couplets composed of: (1) mechanically softer 0.17-m-thick Zone-A and 0.18-m-thick Zone- $C$ with mean values of $U C S=110 \mathrm{MPa}, v=0.25, K_{s}=1.89 \mathrm{MPa} \cdot \sqrt{ } \mathrm{m}$; and (2) mechanically harder 0.41 -m-thick Zone-B and 0.15-m-thick Zone-D which show mean values of $U C S=166 \mathrm{MPa}, v=0.22$, and $K_{s}=2.87 \mathrm{MPa} \cdot \sqrt{ } \mathrm{m}$. Although $X$-ray diffraction analyses of the samples suggest that the entire rock matrix is dominated by dolomite, the harder zones show an abundance of quartz cement $(>30 \%)$ and relatively lower phyllosilicate mineral content $(<2 \%)$ than the softer zones. Further, we observe that the mechanically harder zones have the greatest occurrences and thicknesses of hydrothermal alterations (anhydrite veins and nodules), indicating that the rock had experienced hydrothermal fluid circulation (basinal brines) in the past. We infer that the mechanical stratigraphy most likely influenced the spatial clustering of fractures that facilitated hydrothermal fluid migration in the past, and provides insight that is relevant for the exploitation of geothermal energy resources in sedimentary basins. We suggest that the harder zones or formation intervals with higher ratios of the hard zones relative to soft zones represent viable targets for hydraulic stimulation of a sedimentaryhosted geothermal reservoir, both for the emplacement of new fractures and the linkage of pre-existing fractures to allow efficient fluid circulation. Our findings in this
\end{abstract}


study provide insight that is relevant for understanding the complexity of pre-existing mechanical heterogeneity in sedimentary-hosted geothermal reservoir targets in other places.

Keywords: Enhanced geothermal system, Geomechanics, Hydrothermal alteration, Mechanical stratigraphy, Fracture mechanics, Geothermal energy

\section{Introduction}

Enhanced geothermal systems (EGS) are low-permeability high-temperature reservoirs that have been stimulated to efficiently extract hot water (Nadimi et al. 2020). Hydraulic fracturing is one of the most efficient stimulation techniques currently considered for heat extraction from an EGS, through the injection of highly pressurized fluid into the formation to initiate and propagate or reactivate natural fractures (Murphy et al. 1977; Campbell et al. 1981; Gholizadeh Doonechaly et al. 2013; McClure and Horne 2014; Zhou et al. 2018; Zhang et al. 2020; Kolawole and Ispas 2020a). In assessing a viable geothermal reservoir, three important components are required for consideration; they are heat, mobile fluid, and permeability (Saemundsson et al. 2009; Nadimi et al. 2020). The linkage of hydraulic fractures and preexisting natural fractures has become widely accepted as an important mechanism for fracture network connectivity and permeability enhancement in EGS reservoirs (Pine and Batchelor 1984; McClure and Horne 2014; Finnila et al. 2015; Riahi et al. 2015; Sheng et al. 2018). However, reservoir stimulation models and prediction of in situ rock failure behavior depend on the lithology, in situ stress, fault and preexisting natural fractures (Dotsey and Deighton 2012; Wang and Ghassemi 2012; Stober and Bucher 2013; Shao et al. 2016; Nadimi et al. 2020; Zhang et al. 2020; Ziegler and Heidbach 2020).

Natural geothermal systems are characterized by heterogeneous geology, which includes alteration zones and mineralized fracture networks in the form of veins (e.g., Wyering et al. 2014; Callahan et al. 2019, 2020a). Veins are open fractures that are completely or partially occluded by mineral precipitates. However, the drilling, completion, and production of hot fluids from geothermal reservoirs are expensive field operations, and their success demands an understanding of the complexity of in situ rock mechanical properties (e.g., Wyering et al. 2014; Lund and Toth 2020; Toth 2020). Hydrothermal alterations have significant impact on the mechanical properties of a geothermal reservoir (e.g., Meller and Kohl 2014; Heap et al. 2015; Callahan et al. 2019, 2020b).

However, there is limited understanding of how the pre-alteration (i.e., pre-veining) mechanical properties of rock matrix influence the development of the natural fracture networks that facilitate hydrothermal fluid circulation in geothermal reservoirs in the past. In this study, we address this problem by analyzing a core sample of a hydrothermally-altered sedimentary reservoir from a known low-to-medium temperature geothermal anomaly zone in the Permian Basin, U.S. We show how the rock mechanical properties of the reservoir matrix influenced the development of hydrothermal fluid migration pathways and the implications it poses for efficient exploitation of present-day sedimentary-hosted geothermal resources that require hydraulic stimulation. 


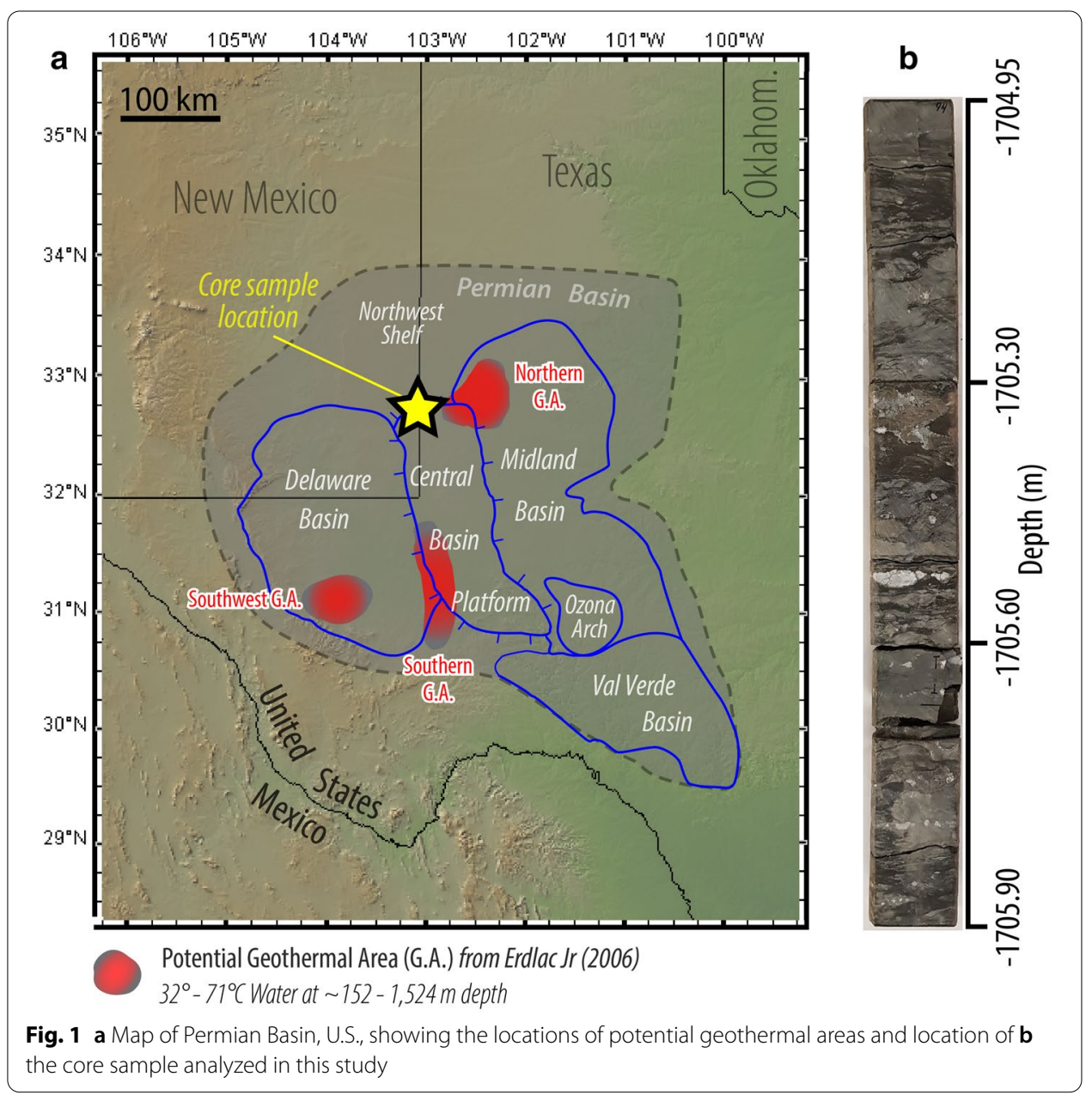

\section{Permian Basin geothermal areas}

The Permian Basin is a large $\left(220,000 \mathrm{~km}^{2}\right)$ Late Paleozoic sedimentary basin, spanning parts of West Texas and Southeastern New Mexico, United States. The Permian Basin is composed of three smaller components known as the Delaware Basin, the Central Basin Platform, and the Midland Basin (Tang 2015). The Central Basin Platform, which lies between the Midland and Delaware Basins, is a zone of Permian tectonic uplift and hosts a significant sequence of carbonate reservoir units, and has a geothermal gradient in the range of $23-29^{\circ} \mathrm{C} / \mathrm{km}$ (Erdlac Jr and Swift 2004; Ruppel et al. 2005). Among these is the prominent San Andres Formation which is known to have a very low porosity of $\sim 3-11 \%$ (average) and average permeability in the range of $0.01-34 \mathrm{mD}$ (Saller et al. 2012). Nodular anhydrites and veins occur in the Permian Basin sedimentary sequences and in varying degrees of clustering within the stratigraphy (Kerr Jr and Thomson 1963; Stueber et al. 1998). Post-deposition of the carbonate sequences, the anhydrite nodules were precipitated by the thermally driven circulation of brines within the basin (Kerr Jr and Thomson 1963).

Major areas of geothermal resource potentials have been identified in the Permian Basin (Erdlac Jr and Swift 2004; Erdlac Jr 2006), among which three are most prominent 
(Geothermal areas, G.A. in Fig. 1a; Erdlac Jr 2006). These areas have low-to-medium temperature geothermal anomalies, characterized by $32-71{ }^{\circ} \mathrm{C}$ hydrothermal systems occurring at 152-1524 m depths within the sedimentary sequences (Erdlac Jr 2006). The heat from low-to-medium temperature geothermal reservoirs might have value for direct heat or heat pump applications because a minimum of $150{ }^{\circ} \mathrm{C}$ is required at reservoir depth for an ORMAT-type organic Rankine cycle (ORC) plant (Kaplan 2007; Quoilin et al. 2013). The northernmost of the three, herein referred to as the Northern G.A. (Fig. 1a), straddles the northwestern Midland Basin and the northeastern corner of the Central Basin Platform. The other geothermal areas include the "Southern G.A." and "Southwest G.A.", located in the southern Central Basin Platform and SW Delaware Basin, respectively (Fig. 1a).

\section{Data and methodology}

\section{Core data}

The core sample analyzed in this study is $0.91 \mathrm{~m}$ long, obtained from the carbonate sequences of the San Andres Formation in the northernmost part of the Central Basin Platform, and near the southern portion of the Northwestern Shelf (Fig. 1a, b). The location corresponds to the SW tip of the Northern G.A. Although these potential geothermal reservoirs are estimated to occur at depths up to $1524 \mathrm{~m}$ (Erdlac Jr 2006), our core sample was obtained from a slightly deeper interval of 1705.0-1705.9 m (Fig. 1b). Thus, the absolute sample depth and higher temperature condition is more representative of the geothermal sedimentary reservoir at the Northern G.A. than reported in the previous study.

We conduct X-ray diffraction (XRD) analyses for different portions of the sample to evaluate the mineralogical characteristics of the core. More specifically, we analyze portions of the rock matrix in the shallowest $(1705.0 \mathrm{~m})$ and deepest $(1705.9 \mathrm{~m})$ sections of the core. Along the entire core, we observe the presence of nodules and veins of varying sizes/thicknesses, characterized by light-colored mineralization (Fig. 2 and Additional file 1: Fig. S1). We obtain a sample from the largest nodule ( $0.02 \mathrm{~m}$-thick) and perform an XRD analysis in order to determine its composition. All the samples were measured in whole-rock condition from $3.5^{\circ}$ to $70^{\circ} 2 \Theta$ at $40 \mathrm{~V} / 40 \mathrm{~A}, 1.5 \mathrm{~s}$ per step with a $1 \mathrm{~mm}$ divergent slit. In addition, we perform a core-scale characterization of the post-diagenetic alterations in the rock, which include the distribution of open fractures, mineralized veins, and nodules. Post-diagenetic alterations refer to changes in the rock after lithification (a process where sediments are compacted and cemented to form rock).

\section{Geomechanical properties}

\section{Estimation of rock strength using the scratch test}

The scratch test is a quasi-non-destructive method based on pushing a tool (cutter) across the surface of a rock at a given penetration depth (ASTM C1624-05 2015; Kolawole and Ispas 2020b). The scratch test method is useful in estimating reservoir geomechanical and petrophysical properties (Detournay and Defourny 1992; Schei et al. 2000; Mitaim et al. 2004; Coudyzer et al. 2005; Dagrain and Germay 2006; Dagrain et al. 2006; Richard et al. 2012; Germay et al. 2015, 2018). The scratch test method (Fig. 3a) measures 


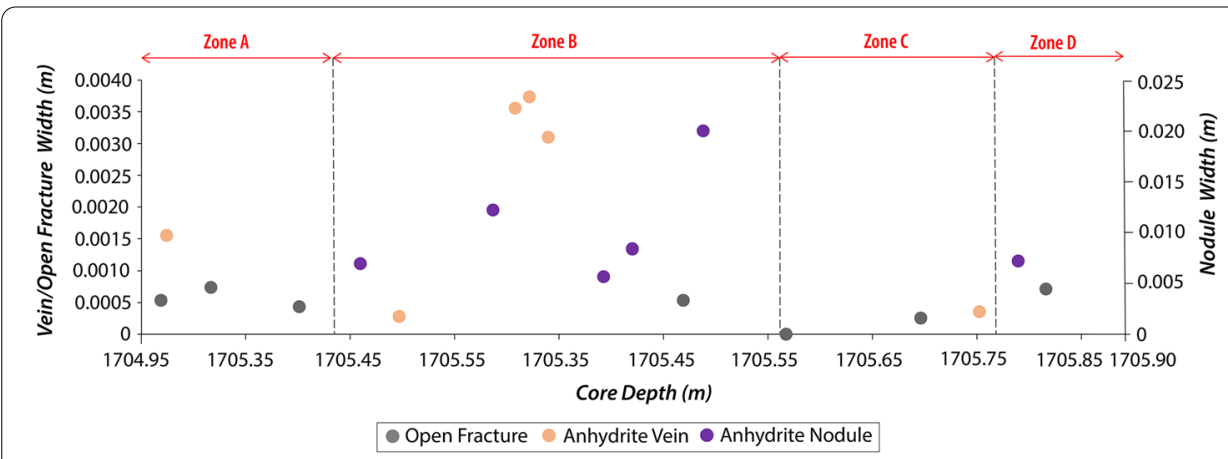

Fig. 2 Distribution of open fractures, mineralized fractures (veins), and anhydrite nodules along the analyzed core. See Fig. $4 \mathrm{~d}-\mathrm{f}$ for the geomechanical analyses supporting the definition of Zones A-D

horizontal $\left(F_{\mathrm{T}}\right)$ and vertical $\left(F_{\mathrm{V}}\right)$ forces exerted during the scratching and estimates the unconfined compressive strength (UCS).

In the scratch tests, a continuous groove in the rock surface is created with a cutting tool. The cutter penetration depth $(d)$ and the cutter velocity relative to the rock are held constant. The horizontal force $\left(F_{\mathrm{T}}\right)$ is parallel to the cutter velocity, and the vertical force $\left(F_{\mathrm{V}}\right)$ is perpendicular to the cutter velocity. The intrinsic specific energy $(\varepsilon)$ is the energy required to scratch a unit volume of rock (Detournay and Defourny 1992; Suarez-Rivera et al. 2002). $\varepsilon$ is presumed to be a rock property characteristic that directly correlates to the rock's unconfined compressive strength $(U C S)$. The scratch cutter-rock interaction model (Detournay and Defourny 1992) and its application to estimate rock strength, combining pure cutting and frictional contact processes are presented in Eqs. 1-6 (for a rectangular cutter) as:

$$
\begin{aligned}
& F_{\mathrm{T}}=\varepsilon(1-\mu \zeta) w d+F_{\mathrm{V}}, \\
& \mu=\tan \phi \\
& E=E_{\mathrm{o}}+\mu S, \\
& E_{\mathrm{O}}=\varepsilon(1-\mu \zeta), \\
& E=\frac{F_{\mathrm{T}}}{w d} \\
& S=\frac{F_{\mathrm{V}}}{w d}
\end{aligned}
$$

where $w$ is the width of the cutter; $d$ is the cutter penetration depth; $\varepsilon$ is the intrinsic specific energy; $\zeta$ is the inclination of the average force acting on the face of the cutter; and $\mu$ is the coefficient of friction on the wear flat/rock interface; $\phi$ is the internal friction angle of the rock; $S$ is the drilling strength of the cutter; and $E$ is the specific energy.

In this study, we use the Wombat scratch machine (Fig. 3b) to scratch our candidate core. The features of the polycrystalline diamond compact (PDC) cutter used for the 
a

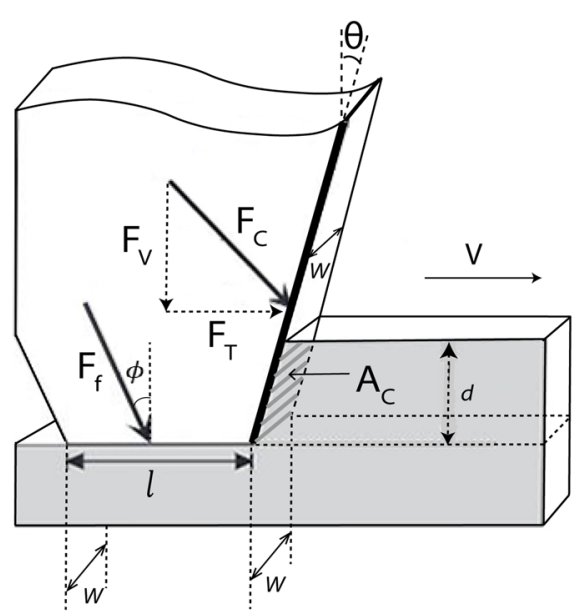

$\mathrm{F}_{\mathrm{T}} \quad$ Horizontal force acting on the cutter face

d Cutter penetration depth

$\mathrm{F}_{\mathrm{V}}$ Vertical force acting on the cutter face

$w$ Width of the cutter

$\mathrm{F}_{\mathrm{C}}$ Cutting force applied on the cutter face

$F_{f} \quad$ Frictional force acting on the cutter face

$A_{C}$ Cross-sectional area of the cutter face

V Cutting velocity

$l$ Contact surface between the cutter and the rock surface

$\theta$ Back-rake angle of the cutter

$\phi \quad$ Internal friction angle of the rock

b

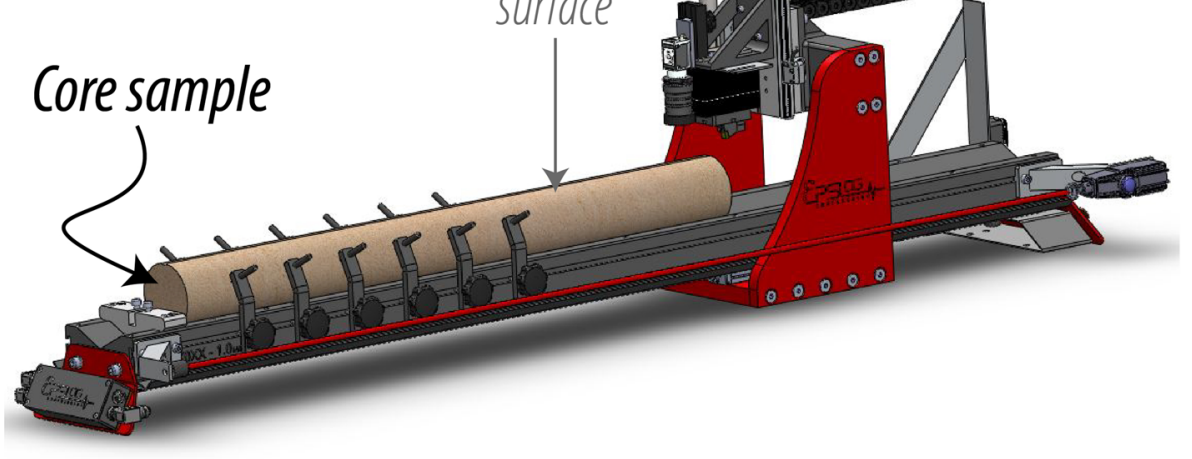

Fig. 3 The scratch test schematic. a Rock scratching configuration for a sharp cutter. b Epslog Wombat machine (pre-modified image courtesy of Epslog S.A.)

scratching include a rectangular-shaped, sharp, flat, with a width $(w)$ of $10 \mathrm{~mm}$, and back-rake angle $(\theta)$ of $15^{\circ}$. In addition, the scratch equipment allows us to acquire an ultra-high-definition panoramic photograph of the full scratch length along the core sample. We use a cylindrical core sample $0.914 \mathrm{~m}$ long and $0.1 \mathrm{~m}$ in diameter, cut nominally perpendicular to the bedding plane. We conduct scratch tests on the core sample at cutter penetration depths $(d)$ of $0.05 \mathrm{~mm}, 0.08 \mathrm{~mm}, 0.11 \mathrm{~mm}, 0.14 \mathrm{~mm}$, $0.17 \mathrm{~mm}, 0.20 \mathrm{~mm}, 0.23 \mathrm{~mm}, 0.26 \mathrm{~mm}$, and $0.29 \mathrm{~mm}$. The data from the scratch test allow us to generate a continuous profile of scratch toughness $\left(K_{\mathrm{s}}\right)$ and Poisson's ratio (v) values along the core. 


\section{Estimation of scratch toughness $\left(K_{\mathrm{s}}\right)$ using the scratch test}

Fracture toughness $\left(K_{\mathrm{IC}}\right)$ is a measure of a material's resistance to fracture propagation, and the propagating fractures tend to travel along the path of least resistance (Chandler et al. 2013; Kolawole and Ispas 2020b). The scratch test method has been utilized and validated for the estimation of scratch toughness $\left(K_{\mathrm{s}}\right)$ of rocks (Ulm and James 2011; Akono 2013; Akono and Ulm 2014; Akono and Kabir 2016; Ante et al. 2018; Kolawole et al. 2021). We consider $K_{\mathrm{s}}$ as a useful proxy for assessing the resistance to fracture propagation in rocks (i.e., a measure of fracture toughness).

In the scratch fracture mechanics model (Akono and Ulm 2011, 2012; Akono et al. 2012), under plane strain conditions the energy release rate, , can be expressed as a function of the scratch forces and the scratch probe geometry using the relationship (Akono and Kabir 2016):

$$
G=\frac{1-v^{2}}{\mathrm{E}} \frac{F_{\mathrm{T}}^{2}}{2 p A}
$$

where $E$ is the Young's modulus, and $v$ is the Poisson's ratio.

For linear elastic isotropic materials under plane strain conditions, the crack propagation occurs when is equal to the fracture energy, ${ }_{f},\left(\right.$ i.e., $=_{f}$ ) (Griffith 1921). Thus, for linear elastic isotropic materials under a fracture-driven regime, the relationship between fracture toughness $\left(K_{\mathrm{IC}}\right)$ and scratch toughness $\left(K_{\mathrm{s}}\right)$ (Akono and Kabir 2016), can be expressed as:

$$
K_{\mathrm{s}}\left(F_{\mathrm{T}}, d\right)=K_{\mathrm{IC}}
$$

For elastic anisotropic materials, Eq. (7) can be further expressed as (Gudmundsson et al. 2010; Akono and Kabir 2016):

$$
G_{\mathrm{f}}=\frac{1-v^{2}}{\mathrm{E}} K_{\mathrm{s}}^{2} .
$$

Therefore, the linear elastic fracture mechanics (LEFM) for anisotropic materials in the estimation of scratch toughness $\left(K_{\mathrm{s}}\right)$ for a rock in relation to the fracture energy release rate is given by the relationship (Akono and Ulm 2011, 2014; Ulm and James 2011; Akono 2013; Akono and Kabir 2016):

$$
K_{\mathrm{s}}=\frac{F_{\mathrm{T}}}{\sqrt{2 p A_{\mathrm{c}}}}[\mathrm{MPa} \cdot \sqrt{\mathrm{m}}],
$$

where $A_{\mathrm{c}}$ is the contact area due to horizontal force $\left(F_{\mathrm{T}}\right)$ in the scratch direction for a rectangular-shaped cutter, $p$ is the fracture surface perimeter for a cutter with a width $(w)$ at a maximum cutting depth $(d)$, and $2 p A_{c}$ is the shape function of the cutter.

\section{Estimation of Poisson's ratio using the scratch test (v)}

Ultrasonic compressional and shear velocities $\left(V_{\mathrm{p}}\right.$ and $\left.V_{\mathrm{s}}\right)$ are used to estimate dynamic Poisson's ratio (v). The $V_{\mathrm{p}}$ and $V_{\mathrm{s}}$ were measured perpendicular to the long axis of the core (Additional file 1: Fig. S2). The dynamic Poisson's ratio and the UCS were independently measured on plugs taken from the same core. 
The experiments in this study are performed in a laboratory with a $28^{\circ} \mathrm{C}$ room temperature and unconfined stress conditions. However, our experimental approach is relevant to geothermal reservoirs because previous laboratory experimental tests under distinct thermal conditions indicated that the effect of temperature is insignificant on rock mechanical properties at temperatures below $200{ }^{\circ} \mathrm{C}$, thus, rheological behavior generally remains the same (Tullis and Yund 1977; Wong 1982; Odedra et al. 2001; Lamdos Santos et al. 2011; Sygała et al. 2013; Wu et al. 2013).

\section{Results}

\section{Core characterization and XRD analysis}

The XRD analyses of the rock matrix (samples from different sections of the core) show that the rock is a dolostone, dominated by dolomite, with varying concentrations of quartz, muscovite, illite, chlorite, and anhydrite (Fig. 4a). The analyses reveal two distinct matrix types in which one has an abundance of quartz cement $(>30 \%)$ and insignificant phyllosilicate mineral content (1.2\% muscovite, no illite or chlorite) relative to the other type, which is deficient in quartz and anhydrite, but rich in phyllosilicate minerals with up to $10 \%$ muscovite, $0.2 \%$ illite, and $0.1 \%$ chlorite (Fig. $4 \mathrm{a}$ ). Also, our results show that the nodule sample is composed of anhydrite with minor quartz and dolomite (Fig. 4a). This suggests that the nodules and veins of light-colored mineralization observed in the core sample (Figs. $1 \mathrm{~b}$ and $4 \mathrm{~b}$ ) are largely composed of anhydrites. The veins show sub-vertical (core-parallel), low-angle dips, and sub-horizontal (core-perpendicular) geometries, whereas the open fractures observed only show sub-horizontal geometries. Overall, we find that the greatest clustering of the anhydrite veins and nodules occur within the $0.41-\mathrm{m}$-thick interval, located in the central part of the core. However, the open fractures appear to be evenly distributed along the core length, and since the open fractures pre-existed in situ, we suspect they might be opened due to stress relaxation.

\section{Unconfined compressive strength (UCS)}

The $U C S$ color contours in Fig. 4d indicate the variations from low to high strength along the core. The continuous scratch test $U C S \log$ profile of the core shows that the highest $U C S$ values occur at depth intervals of 1705.12-1705.53 m (0.41-m-thick Zone B) and 1705.71-1705.86 m (0.15-m-thick Zone D), and are separated by intervals of relatively lower $U C S$ values at $1704.95-1705.12 \mathrm{~m}(0.17$-m-thick Zone A) and 1705.53-1705.71 m (0.18-m-thick Zone C).

\section{Ultrasonic velocities $(V p, V s)$ and Poisson's ratio $(v)$}

The measured ultrasonic shear $\left(V_{\mathrm{s}}\right)$ and compressional $\left(V_{\mathrm{p}}\right)$ velocities and the corresponding Poisson's ratio along the core show the distribution of heterogeneous mechanical properties along the core (Fig. 4e and Additional file 1: Fig. S2). Although the measured velocities show considerable variations along the core, the broad trends in the data correlate with the zoning of the rock strength estimates (Additional file 1: Fig. S2). Overall, the calculated Poisson's ratio distribution is most salient, showing more correlations with each of the zones. Similar to the distribution of UCS, we 


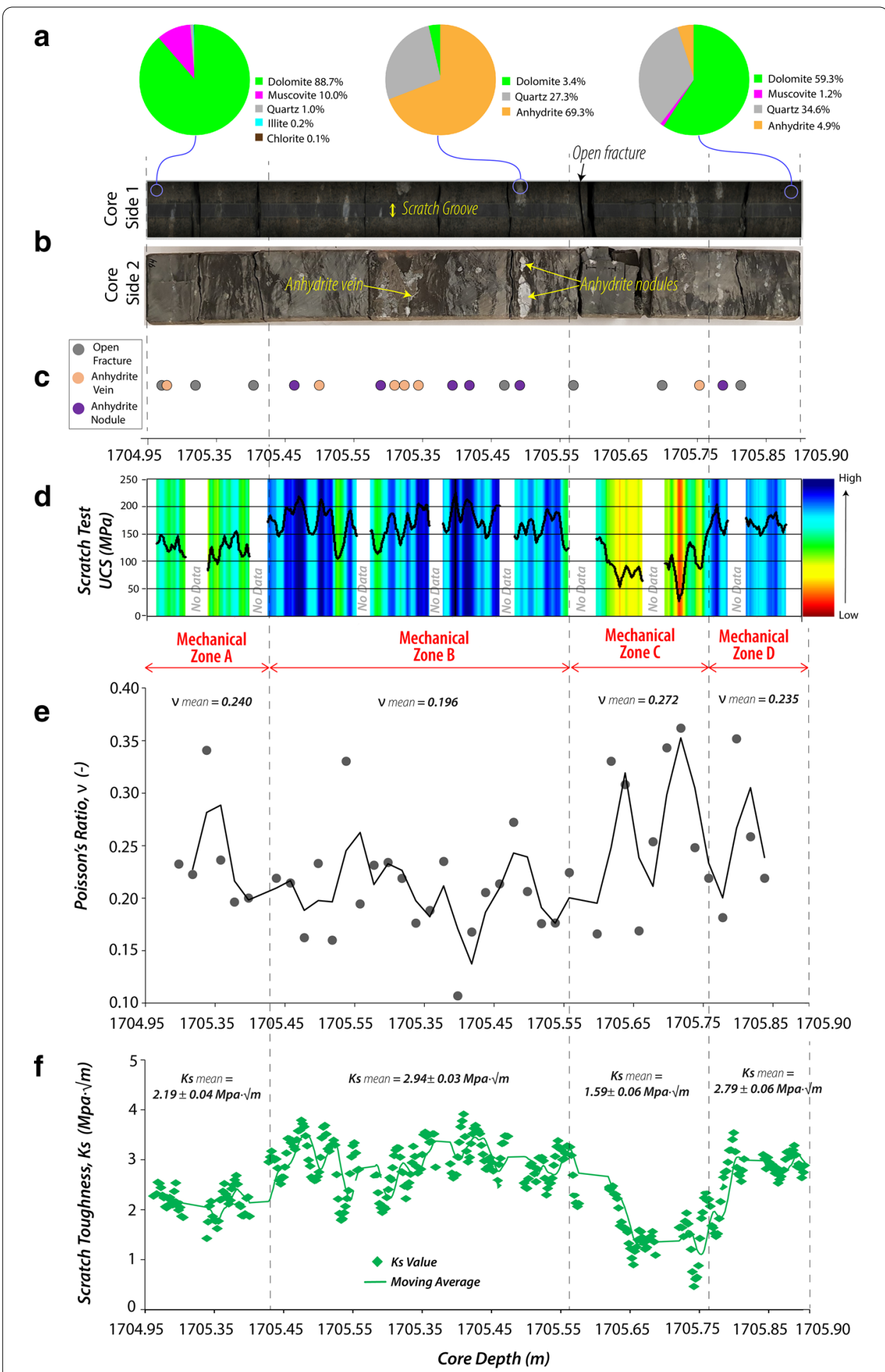

Fig. 4 a X-ray diffraction (XRD) analysis of the core sample; $\mathbf{b}$ digital photography of core sample; $\mathbf{c}$ core-scale characterization; $\mathbf{d}$ scratch test unconfined compressive strength (UCS); e dynamic Poisson's ratio $(v) ; \mathbf{f}$ scratch toughness $\left(K_{s}\right)$ 
observe that the mechanical Zones $\mathrm{A}$ and $\mathrm{C}$ show relatively higher Poisson's ratios compared to the intervening Zones B and D (Fig. 4e).

\section{Scratch toughness $\left(K_{s}\right)$}

We present the estimates of scratch toughness along the core in Fig. 4f. Again, the distribution of the values and the trend of the moving average fitting curve also show that there exists a zonation in scratch toughness along the core. Within Zones A and $\mathrm{C}, K_{\mathrm{s}}$ shows the least values (as low as $0.46 \mathrm{MPa} \cdot \sqrt{ } \mathrm{m}$ ), whereas, in Zones B and D, the $K_{s}$ is highest, attaining a maximum of $3.9 \mathrm{MPa} \cdot \sqrt{ } \mathrm{m}$. We note that these $K_{\mathrm{s}}$ values are consistent with the range of results in published literature on fracture toughness of dolomitic rocks $(1.67-8.59 \mathrm{MPa} \cdot \sqrt{ } \mathrm{m}$ ) (Backers and Stephansson 2012; Yao et al. 2020), limestones $(0.36-2.0 \mathrm{MPa} \cdot \sqrt{ } \mathrm{m})$ (Castle et al. 2006), and silicified hydrothermally altered rocks $(0.56-3.84 \mathrm{MPa} \cdot \sqrt{ } \mathrm{m}$ ) (Atkinson 1984; Callahan 2018; Callahan et al. 2019).

\section{Discussion}

\section{Mechanical zonation within the analyzed core sample}

The distribution of open fractures, mineralized veins, and nodules show correlations with the zonation of mechanical strength along the core (Fig. 4c and d). We observe that the largest nodules and thickest veins occur in the hardest Zones B and D. These harder zones also correspond to the intervals with the highest values of $U C S$ and $K_{\text {s }}$, and lowest values of Poisson's ratio. These zones B and D are separated by mechanically softer zones (Zones A and C; Fig. 4d-f). The delineation of the hard and soft zones, based on the UCS, indicates the stiffness of the mechanical zones in the rock (Deere 1968; Palchik 1999, 2011; Yılmaz and Sendır 2002; Al-Shayea 2004; Gokceoglu and Zorlu 2004; Sonmez et al. 2004; Zoback 2010).

Our XRD analyses (Fig. 4a, b) examined one of the mechanically harder zones (Zone D) and one of the softer zones (Zone A). The results show that the hard zone is dominated by a mix of dolomite, quartz, and anhydrite-rich matrix, whereas the softer zone is enriched in phyllosilicate minerals (chlorite, muscovite, and illite) within a dolomitic matrix. Rocks that are rich in phyllosilicate minerals are significantly mechanically softer in comparison to quartz, dolomite, and anhydrite-rich rocks (Brindley 1981; Tesei et al. 2012). Muscovite has an estimated UCS of 50-75 MPa, illite $<10 \mathrm{MPa}$, anhydrite $150 \mathrm{MPa}$, quartz 200-290 MPa, and dolomite $140 \mathrm{MPa}$ (Nataraj 1991; Tham et al. 2001; Chen et al. 2004; Dalamarinis et al. 2009; Majdi and Rezaei 2013; Hantler 2015; Wang et al. 2019; Callahan et al. 2019, 2020b). Thus, we suggest that mechanical zonation is primarily influenced by the relative distribution or clustering of mineral types along the generally dolomitic matrix, more specifically the relative percentage concentrations of the quartz, anhydrite, and phyllosilicate cements.

Further, we note that the harder zones have mean values of $166 \mathrm{MPa} U C S, 0.22 v$, and $2.87 \mathrm{MPa} \cdot \sqrt{ } \mathrm{m} K_{\mathrm{s}}$ (Fig. $4 \mathrm{~d}-\mathrm{f}$ ), supporting the XRD results which show that the harder zones are more enriched in quartz and anhydrite than the softer zones. Whereas, the mechanically softer zones have mean values of $110 \mathrm{MPa} U C S, 0.25 \mathrm{v}$, and $1.89 \mathrm{MPa} \cdot \sqrt{ } \mathrm{m}$ $K_{\mathrm{s}}$, also consistent with the XRD results showing a relatively greater abundance of 
phyllosilicate minerals in these zones relative to the harder zones (Fig. 4a-d). These observations suggest that the analyzed core exhibits prominent mechanical stratigraphy expressed in the form of soft-hard (less stiff-to-stiff) zonation couplets which may have influenced the emplacement of brittle deformation which later served as conduits for hydrothermal fluid migration in the past. This mechanical stratigraphy, related to the along-core variation of cement mineral types, was most likely emplaced during the diagenetic development of the dolostone rock, prior to fracture development and later veining. Also, the presence of occluded fractures (i.e., veins) indicate that this formation was a permeable reservoir at the time of veining, and that fractures played an important role in the circulation of the basinal brines.

\section{The implications for the enhanced geothermal system (EGS) development}

Our results indicate that the fractures that strongly facilitated hydrothermal fluid circulation in the past were preferentially localized in hard Zones B and D of the analyzed core (Fig. 4c). Our analyses show that the mechanical property of the reservoir rock controls the emplacement of fluid circulation pathways in the past. We suggest that our observation of the influence of mechanical stratigraphy on ancient hydrothermal circulation is relevant to the present-day extraction of heat from EGS sedimentary reservoirs in other places where similar mechanical structure is present.

Following LEFM analytical solutions (Eq. 9), rocks with higher $K_{\mathrm{s}}$ values will have higher fracture energy ${ }_{f}$, suggesting more efficient fracture development in the harder/ stiffer Zones B and C (Fig. 4f). This is consistent with previous field observations and analytical solutions (Gudmundsson et al. 2010) which demonstrate that fractures propagating from a stiff layer towards a softer one tend to propagate more efficiently and commonly penetrate the contacts. This principle has been widely used in the hydraulic stimulation of unconventional hydrocarbon reservoirs in the U.S. such as the prolific Woodford, Eagle Ford, Duvernay, Monterey, Niobrara, Wolfcamp Shale Formations (Laubach et al. 2009; Slatt and Abousleiman 2011; Ferrill et al. 2014; Galvis et al. 2018). For example, the Woodford Shale is characterized by soft-hard (less stiff-to-stiff) bed couplets where intervals with the proper ratio of soft (organic rich) to hard (cherty, organic poor) zones are preferentially targeted for lateral well landings and hydraulic stimulation (e.g., Slatt and Abousleiman 2011; Galvis et al. 2018).

Thus, we argue that the presence of mechanical heterogeneity (e.g., mechanical stratigraphy) in sedimentary geothermal reservoirs pose important implications for efficient fracture stimulation and production of heat from such reservoirs. More specifically, in geothermal reservoirs with soft-hard couplets of mechanical stratigraphy as observed in this study, we suggest that the harder zones or formation intervals with higher ratios of the hard zones relative to the soft zones represent viable targets for hydraulic stimulation of the reservoir. This is critical for both the emplacement of new fractures and the linkage of pre-existing fractures to allow efficient hot fluid circulation.

Furthermore, the exploration of geothermal energy systems has been associated with induced seismicity (Diehl et al. 2017; Wiemer et al. 2017; Cheng and Chen 2018; Zbinden et al. 2020). However, carbonate minerals (calcite and dolomite), are mechanically more susceptible to earthquake nucleation at higher temperatures and pressures such as those relevant for deep hydrothermal reservoirs (e.g., Carpenter 
et al. 2014; Kolawole et al. 2019). Therefore, we suggest that there is a need to better understand the relationships between secondary alterations, mechanical zonation, and frictional stability in relation to earthquake susceptibility in the development of enhanced geothermal systems (EGS).

\section{Upscaling core-scale observations to reservoir scale}

Continuous sampling with a scratch test machine provides a fine-scale and detailed measurement of mechanical properties along a core sample (e.g., data points in Fig. $4 \mathrm{~d}-\mathrm{f}$ ), whereas the larger-scale trends describe the bulk mechanical properties of the rock (e.g., the color contour of UCS in Fig. 4d). In this study, we analyzed only 0.91-m-long core within the San Andres reservoir, and we observed both the detailed and bulk mechanical heterogeneity, but at the scale of the core. We clarify that the sedimentary reservoir studied here is not yet proven as a viable EGS field, primarily because a minimum of $150^{\circ} \mathrm{C}$ is required at reservoir depth for an ORMAT-type ORC plant. However, our findings provide insight that is relevant for understanding the complexity of pre-existing mechanical heterogeneity in sedimentary-hosted geothermal reservoir targets in other places.

More importantly, there is a need to characterize our observed mechanical heterogeneity at reservoir-scale, and upscale our results to explicitly model the geomechanical response during hydraulic stimulation. In modeling, the heterogeneity of geology (mineral matrix compositions, distributed (nodules) and localized (veins) hydrothermal alterations, and pre-existing fractures) and mechanical heterogeneity of rock strength, fracture toughness, and Poisson's ratio, should be considered to develop models that can accurately predict reservoir-scale and sub-reservoir scale fracture behavior. Finally, we highlight that our study presents a useful workflow for quasi-non-destructive continuous geomechanical characterization of geothermal reservoirs core samples.

\section{Conclusions}

In this study, we examine the distribution of mechanical properties (unconfined compressive strength, $U C S$; ultrasonic velocity-derived Poisson ratio, v; and, scratch toughness, $K_{\mathrm{s}}$ ) along the cored interval of a sedimentary formation with a known geothermal anomaly in the Permian Basin, U.S. In addition, we performed a core-scale characterization of the post-diagenetic hydrothermal alterations in the rock, and XRD analyses to further characterize the mineralogic compositions of the rock.

Our findings from this study reveal:

a. The mechanical heterogeneity of the rocks is demonstrated by four distinct alternating mechanical zones, which include: mechanically softer 0.17 -m-thick Zone$\mathrm{A}$ and 0.18 -m-thick Zone-C showing mean values of $U C S=110 \mathrm{MPa}, v=0.25$, $K_{\mathrm{s}}=1.89 \mathrm{MPa} \cdot \sqrt{ } \mathrm{m}$; and mechanically harder 0.41 -m-thick Zone-B and 0.15 -m-thick Zone-D which show mean values of $U C S=166 \mathrm{MPa}, v=0.22, K_{\mathrm{s}}=2.87 \mathrm{MPa} \cdot \sqrt{ } \mathrm{m}$.

b. A lower abundance of phyllosilicate minerals and higher abundance of quartz and anhydrite in mechanically harder zones, whereas there is a higher abundance of 
phyllosilicate minerals and deficiency of quartz and anhydrite in mechanically softer zones.

c. The investigated core experienced hydrothermal fluid migration in the past, which was facilitated by the mechanical stratigraphy, demonstrated by a preferential localization of permeable fractures within the mechanically harder zones of the rock.

d. A high degree of mechanical heterogeneity in a sedimentary geothermal reservoir will influence fracture development and propagation, and more importantly the stimulation and extraction of heat from sedimentary-hosted enhanced geothermal systems (EGS).

e. We suggest that the harder zones or formation intervals with higher ratios of the hard zones relative to soft zones represent viable targets for hydraulic stimulation of a sedimentary-hosted geothermal reservoir.

Our findings in this study are relevant for understanding the complexity of pre-existing mechanical heterogeneity in sedimentary-hosted geothermal reservoir targets in other places. We suggest that this work provides novel insights into the understanding of how the mechanical heterogeneity of rock properties may influence fracture stimulation and production of hot fluids from sedimentary-hosted EGS reservoirs. In addition, our study presents a useful workflow for quasi-non-destructive continuous geomechanical characterization of geothermal reservoirs.

\section{Abbreviations}

EGS: Enhanced geothermal systems; G.A.: Geothermal areas; UCS: Unconfined compressive strength; $v$ : Poisson's ratio; $K_{s}$ : Scratch toughness; $V_{\mathrm{p}}$ : Ultrasonic compressional velocity; $V_{s}$ : Ultrasonic shear velocity; NF: Pre-existing natural fractures; ORC: ORMAT-type organic Rankine cycle; XRD: X-ray diffraction.

\section{Supplementary Information}

The online version contains supplementary material available at https://doi.org/10.1186/s40517-021-00195-y.

Additional file 1: Figure S1. Physical characterization of the core sample. Figure S2. Ultrasonic shear and compressional velocities, and dynamic Poisson's ratio. Figure S3. XRD quantification results.

Acknowledgements

The authors would like to acknowledge Steward Energy II for providing the core used in this study. We also want to thank the anonymous reviewers and the scientific community for their insightful comments that helped us to improve the quality of our manuscript.

\section{Authors' contributions}

OK and FK conceptualized the project. OK conducted the experimental investigations and processed the data. OK conducted the core-scale characterization with support from FK. OK analyzed and interpreted the data, and wrote the manuscript. FK guided the interpretation of the results and supported the writing of the manuscript. II, CG, and JDM edited and improved the manuscript. All authors read and approved the final manuscript.

Funding

No external funding was received for this study.

Availability of data and materials

The datasets generated and/or analyzed during the current study are available in the Mendeley data repository (Kolawole et al. 2020)

\section{Declarations}

Competing interests

The authors declare that they have no competing interests. 


\section{Author details}

${ }^{1}$ Rock Mechanics Laboratory, Texas Tech University, 101 Terry Fuller Petroleum Engineering Research Building, Lubbock, TX, USA. ' ${ }^{2}$ Bob L. Herd Department of Petroleum Engineering, Texas Tech University, Lubbock, TX, USA. ${ }^{3}$ School of Geosciences, University of Oklahoma, Norman, OK, USA. ${ }^{4}$ Present Address: BP America Inc., Houston, TX, USA. ${ }^{5}$ EPSLOG S.A., Liege, Belgium. ${ }^{6}$ Department of Chemical Engineering, University of Utah, Salt Lake City, UT, USA.

Received: 2 December 2020 Accepted: 26 April 2021

Published online: 08 May 2021

\section{References}

Akono AT. Assessment of fracture properties and rate effects on fracture of materials by micro scratching: application to gas shale. Doctoral dissertation, Massachusetts Institute of Technology. 2013;69-76.

Akono AT, Kabir P. Microscopic fracture characterization of gas shale via scratch testing. Mech Res Commun. 2016;78:86-92.

Akono A-T, Ulm F-J. Scratch test model for the determination of fracture toughness. Eng Fract Mech. 2011;78:334-42. https://doi.org/10.1016/j.engfracmech.2010.09.017.

Akono A-T, Ulm F-J. Fracture scaling relations for scratch tests of axisymmetric shape. J Mech Phys Solids. 2012;60(3):37990. https://doi.org/10.1016/j.jmps.2011.12.009.

Akono A-T, Ulm F-J. An improved technique for characterizing the fracture toughness via scratch test experiments. Wear. 2014;313:117-24. https://doi.org/10.1016/j.wear.2014.02.015.

Akono A-T, Randall NF, Ulm F-J. Experimental determination of the fracture toughness via microscratch tests: application to polymers, ceramics, and metals. J Mater Res. 2012;27:485-93. https://doi.org/10.1557/jmr.2011.402.

Al-Shayea NA. Effect of testing methods and conditions on the elastic properties of limestone rock. Eng Geol. 2004;74:139-56. https://doi.org/10.1016/j.enggeo.2004.03.007.

Ante MA, Manjunath GL, Aminzadeh F, Jha B. Microscale laboratory studies for determining fracture directionality in tight sandstone and shale during hydraulic fracturing. In: Unconventional resources technology conference. 2018. https://doi.org/10.15530/URTEC-2018-2903021.

ASTM C1624-05. Standard test method for adhesion strength and mechanical failure modes of ceramic coatings by quantitative single point scratch testing. West Conshohocken: ASTM International; 2015. https://doi.org/10.1520/ C1624-05R15.

Atkinson BK. Subcritical crack growth in geological materials. J Geophys Res. 1984;89(B6):4077-114. https://doi.org/10. 1029/JB089iB06p04077.

Backers T, Stephansson O. ISRM suggested method for the determination of mode II fracture toughness. Rock Mech Rock Eng. 2012;45:1011-22. https://doi.org/10.1007/978-3-319-07713-0_4.

Brindley GW. Phyllosilicates. In: Mineralogy. Encyclopedia of Earth Science. Boston: Springer; 1981. https://doi.org/10 1007/0-387-30720-6_100.

Callahan OA. Interactions between chemical alteration, fracture mechanics, and fluid flow in hydrothermal systems. Ph.D. Dissertation, The University of Texas at Austin. 2018. http://hdl.handle.net/2152/68884.

Callahan OA, Eichhubl P, Davatzes NC. Mineral precipitation as a mechanism of fault core growth. J Struct Geol. 2020a. https://doi.org/10.1016/j.jsg.2020.104156.

Callahan OA, Eichhubl P, Olson JE, Davatzes NC. Experimental investigation of chemically aided fracture growth in silicified fault rocks. Geothermics. 2020b. https://doi.org/10.1016/j.geothermics.2019.101724.

Callahan OA, Eichhubl P, Olson JE, Davatzes NC. Fracture mechanical properties of damaged and hydrothermally altered rocks, Dixie Valley-Stillwater Fault Zone, Nevada, USA. J Geophys Res Solid Earth. 2019;124(4):4069-90. https://doi. org/10.1029/2018JB016708.

Campbell DA, Morris CW, Verity RV. Geothermal well stimulation experiments and evaluation. Soc Pet Eng. 1981. https:// doi.org/10.2118/10316-MS.

Carpenter BM, Scuderi MM, Collettini C, Marone C. Frictional heterogeneities on carbonate-bearing normal faults: insights from the Monte Maggio Fault. Italy J Geophys Res Solid Earth. 2014;119(12):9062-76. https://doi.org/10. 1002/2014JB011337.

Castle JW, Falta RW, Bruce D, Murdoch L, Brame SE, Brooks D. Fracture dissolution of carbonate rock: an innovative process for gas storage. US Department of Energy, DE-FC26-02NT41299. (2006) https://doi.org/10.2172/918425. Accessed 05 Dec 2020.

Chandler M, Meredith P, Crawford B. Experimental determination of the fracture toughness the Mancos shale, Utah. Geophys Res Abstr. 2013. https://doi.org/10.3997/2214-4609.20130286.

Chen S, Yue ZQ, Tham LG. Digital image-based numerical modeling method for prediction of inhomogeneous rock failure. Int J Rock Mech Min Sci. 2004;41:939-57. https://doi.org/10.1016/j.jirmms.2004.03.002.

Cheng Y, Chen X. Characteristics of seismicity inside and outside the Salton Sea geothermal field. Bull Seismol Soc Am. 2018;108(4):1877-88. https://doi.org/10.1785/0120170311.

Coudyzer C, Poyol E, Bette P, Dagrain F. Measure of rock mechanical properties from scratching test. In: AAPG international conferences and exhibition. 2005

Dagrain F, Germay C. Fields applications for the scratching tests. In: The Eurock 2006: multiphysics coupling and long term behaviour in rock mechanics. CRC Press; 2006. p. 571-6.

Dagrain F, Richard T, Germay C. The rock strength device: a scratching apparatus to determine rock properties. In: The 7th national congress on theoretical and applied mechanics, NCTAM. 2006.

Dalamarinis P, Kelessidis VC, Chatzistamou V, Karydakis G, Chlaboutakis M. Analysis of water and geothermal-well shallow drilling data via drilling software allows for rock drillability assessment and drill bit performance. In: 3rd AMIREG 
international conference: assessing the footprint of resource utilization and hazardous waste management, Athens, Greece. 2009.

Deere DU. Geological considerations. In: Stagg KG, Zienkiewicz OC, editors. Rock mechanics in engineering practice. London: Wiley; 1968. p. 1-20.

Detournay E, Defourny P. A phenomenological model for the drilling action of drag bits. Int J Rock Mech Min Sci Geomech Abstr. 1992;29:13-23. https://doi.org/10.1016/0148-9062(92)91041-3.

DiehI T, Kraft T, Kissling E, Wiemer S. The induced earthquake sequence related to the St. Gallen deep geothermal project (Switzerland): fault reactivation and fluid interactions imaged by microseismicity. J Geophys Res Solid Earth. 2017;122(9):7272-90. https://doi.org/10.1002/2017jb014473.

Dotsey P, Deighton I. New approach to basin formation temperature modelling. First Break. 2012. https://doi.org/10. 3997/1365-2397.30.12.65624.

Erdlac Jr RJ. A resource assessment of geothermal energy resources for converting deep gas wells in carbonate strata into geothermal extraction wells: a Permian Basin evaluation. U.S. Department of Energy Office of Energy Efficiency and Renewable Energy, EERE. (2006) https://doi.org/10.2172/893183. Accessed 17 June 2020.

Erdlac Jr RJ, Swift DB. Deep permeable strata geothermal energy (DPSGE): tapping giant heat reservoirs within deep sedimentary basins — an example from Permian Basin carbonate strata. GRC Trans. 2004;28:327-31.

Ferrill DA, McGinnis RN, Morris AP, Smart KJ, Sickmann ZT, Bentz M, Lehrmann D, Evans MA. Control of mechanical stratigraphy on bed restricted jointing and normal faulting, eagle Ford Formation, south-central Texas. AAPG Bull. 2014;98:2477-506. https://doi.org/10.1306/08191414053.

Finnila A, Dershowitz W, Doe T, McLaren R. Hydro-shearing and hydraulic fracturing for enhanced geothermal systems in archetypical normal, strike-slip and thrust faulting terrains. GRC Trans. 2015;39:1-19.

Galvis H, Becerra D, Slatt R. Lithofacies and stratigraphy of a complete Woodford Shale outcrop section in South Central Oklahoma: geologic considerations for the evaluation of unconventional shale reservoirs. Interpretation. 2018;6(1):SC15-27. https://doi.org/10.1190/INT-2017-0074.1.

Germay C, Richard T, Mappanyompa E, Lindsay C, Kitching D, Khaksar A. The continuous-scratch profile: a high-resolution strength log for geomechanical and petrophysical characterization of rocks. Soc Pet Eng. 2015;18(03):432-40.

Germay C, Lhomme T, McPhee C, Daniels G. An objective review of non-destructive methods for the direct testing of strength on rock cores. American Rock Mechanics Association; 2018.

Gholizadeh Doonechaly N, Rahman SS, Kotousov A. A new approach to hydraulic stimulation of geothermal reservoirs by roughness induced fracture opening. In: Bunger AP, McLennan J, Jeffrey R, editors. Effective and sustainable hydraulic fracturing. London: IntechOpen; 2013. p. 573-90. https://doi.org/10.5772/56447.

Gokceoglu C, Zorlu K. A fuzzy model to predict the uniaxial compressive strength and modulus of elasticity of problematic rocks. Eng Appl Artif Intell. 2004:17(1):61-72. https://doi.org/10.1016/j.engappai.2003.11.006.

Griffith AAVI. The phenomena of rupture and flow in solids. Philos Trans R Soc Lond. 1921;221:163-98. https://doi.org/10. 1098/rsta.1921.0006.

Gudmundsson A, Simmenes TH, Larsen B, Philipp SL. Effects of internal structure and local stresses on fracture propagation, deflection, and arrest in fault zones. J Struct Geol. 2010;32(11):1643-55. https://doi.org/10.1016/j.jsg.2009.08. 013.

Hantler A. Crushing index-Aitik. Technical report, no. 8HX286586.10, Pöyry Sweden AB. 2015.

Heap MJ, Kennedy BM, Pernin N, Jacquemard L, Baud P, Farquharson Jl, et al. Mechanical behaviour and failure modes in the Whakaari (White Island volcano) hydrothermal system, New Zealand. J Volcanol Geotherm Res. 2015;295:26-42. https://doi.org/10.1016/j.jvolgeores.2015.02.012.

Kaplan U. Organic rankine cycle configurations. In: European Geothermal Congress, Unterhaching, Germany. 2007.

Kerr SD Jr, Thomson A. Origin of nodular and bedded anhydrite in permian shelf sediments, Texas and New Mexico. AAPG Bull. 1963. https://doi.org/10.1306/BC743BOB-16BE-11D7-8645000102C1865D.

Kolawole $\mathrm{O}$, Ispas I. Interaction between hydraulic fractures and natural fractures: current status and prospective directions. J Pet Explor Prod Technol. 2020a;10:1613-34. https://doi.org/10.1007/s13202-019-00778-3.

Kolawole O, Ispas I. Evaluation of geomechanical properties via scratch tests: where are we and where do we go from here? SN Appl Sci. 2020b;2(10):1-14. https://doi.org/10.1007/s42452-020-03469-5.

Kolawole F, Johnston CS, Morgan CB, Chang JC, Marfurt KJ, Lockner DA, Reches Z, Carpenter BM. The susceptibility of Oklahoma's basement to seismic reactivation. Nat Geosci. 2019;12:839-44. https://doi.org/10.1038/ s41561-019-0440-5.

Kolawole O, Ispas I, Kolawole F, Germay C, McLennan JD. Scratch test characterization of heterogeneous rock mechanical properties with applications to enhanced geothermal systems. Mendeley Data. 2020. https://doi.org/10 $17632 / x w h n k z z d m m .4$.

Kolawole O, Ispas I, Kumar M, Weber J, Zhao B. Time-lapse biogeomechanical modified properties of ultra-low permeability reservoirs. Rock Mech Rock Eng. 2021. https://doi.org/10.1007/s00603-021-02410-5.

Lamdos Santos JP, Rosa LG, Amaral PM. Temperature effects on mechanical behaviour of engineered stones. Constr Build Mater. 2011;25(1):171-4. https://doi.org/10.1016/..conbuildmat.2010.06.042.

Laubach SE, Olson JE, Gross MR. Mechanical and fracture stratigraphy. AAPG Bull. 2009;93:1413-26. https://doi.org/10. 1306/07270909094.

Lund JW, Toth AN. Direct utilization of geothermal energy 2020 worldwide review. Geothermics. 2020;90:101915. https:// doi.org/10.1016/j.geothermics.2020.101915.

Majdi A, Rezaei M. Prediction of unconfined compressive strength of rock surrounding a roadway using artificial neural network. Neural Comput Appl. 2013;23:381-9. https://doi.org/10.1007/s00521-012-0925-2.

McClure MW, Horne RN. An investigation of stimulation mechanisms in enhanced geothermal systems. Int J Rock Mech Min Sci. 2014;72:242-60. https://doi.org/10.1016/j.jirmms.2014.07.011.

Meller C, Kohl T. The significance of hydrothermal alteration zones for the mechanical behavior of a geothermal reservoir. Geotherm Energy. 2014;2:12. https://doi.org/10.1186/s40517-014-0012-2.

Mitaim S, Dagrain F, Richard T, Detournay E, Drescher A. A novel apparatus to determine the rock strength parameters. In: The 9th national convention on civil engineering, Thailand. 2004. 
Murphy HD, Lawton RG, Tester JW, Potter RM, Brown DW, Aamodt RL. Preliminary assessment of a geothermal energy reservoir formed by hydraulic fracturing. Soc Pet Eng. 1977;17(04):317-26.

Nadimi S, Forbes B, Moore J, Podgorney R, McLennan JD. Utah FORGE: hydrogeothermal modeling of a granitic based discrete fracture network. Geothermics. 2020. https://doi.org/10.1016/j.geothermics.2020.101853.

Nataraj MS, et al. Preliminary geotechnical evaluation of deep borehole facilities for nuclear waste disposal in shales. In: Bennett RH, et al., editors. Microstructure of fine-grained sediments. Frontiers in sedimentary geology. New York: Springer; 1991. https://doi.org/10.1007/978-1-4612-4428-8_57.

Odedra A, Ohnaka M, Mochizuki H, Sammonds P. Temperature and pore pressure effects on the shear strength of granite in the brittle-plastic transition regime. Geophys Res Lett. 2001;28(15):3011-4. https://doi.org/10.1029/2001GL0133 21.

Palchik V. Influence of porosity and elastic modulus on uniaxial compressive strength in soft brittle porous sandstones. Rock Mech Rock Eng. 1999;32(4):303-9. https://doi.org/10.1007/s006030050050.

Palchik V. On the ratios between elastic modulus and uniaxial compressive strength of heterogeneous carbonate rocks. Rock Mech Rock Eng. 2011;44:121-8. https://doi.org/10.1007/s00603-010-0112-7.

Pine RJ, Batchelor AS. Downward migration of shearing in jointed rock during hydraulic injections. Int J Rock Mech Min Sci Geomech Abstr. 1984;21:249-63. https://doi.org/10.1016/0148-9062(84)92681-0.

Quoilin S, Van Den Broek M, Declaye S, Dewallef P, Lemort V. Techno-economic survey of organic Rankine cycle (ORC) systems. Renew Sust Energy Rev. 2013;22:168-86. https://doi.org/10.1016/j.rser.2013.01.028.

Riahi A, Radakovic-Guzina Z, Damjanac B, Katsaga T. Three-dimensional numerical investigation of the effect of injection method on shear stimulation of enhanced geothermal reservoirs. American Rock Mechanics Association, ARMA2015-869; 2015 .

Richard T, Dagrain F, Poyol E, Detournay E. Rock strength determination from scratch tests. Eng Geol. 2012;147-148:91-100.

Ruppel SC, Jones RH, Breton CL, Kane JA. Preparation of maps depicting geothermal gradient and Precambrian structure in the Permian Basin. In: USGS Order no. 04CRSA0834 and Requisition no. 04CRPR01474. 2005.

Saemundsson, K, Axelsson G, Steingrímsson B. Geothermal systems in global perspective. Short course on exploration for geothermal resources, UNU GTP. 2009;11.

Saller A, Bierly L, Shafer D, Owens L. Contrasting styles of San Andres reservoirs: vacuum versus slaughter fields, Middle Permian, West Texas and Southeast New Mexico. In: AAPG annual convention and exhibition. 2012.

Schei G, Fjær E, Detournay E, Kenter CJ, Fuh GF, Zausa F. The scratch test: an attractive technique for determining strength and elastic properties of sedimentary rocks. Society of Petroleum Engineers. 2000.

Shao H, Hein P, Sachse A, Kolditz O. Geoenergy modeling II: shallow geothermal systems. Springer briefs in energy: computational modeling of energy systems. Cham: Springer; 2016. https://doi.org/10.1007/978-3-319-45057-5.

Sheng M, Xu Z, Wang X, Li P. Experimental study on hydro-shearing propagation of an embedded fracture in hot dry granite rock. GRC Trans. 2018;42.

Slatt RM, Abousleiman Y. Merging sequence stratigraphy and geomechanics for unconventional gas shales. Lead Edge. 2011;30:274-82. https://doi.org/10.1190/1.3567258.

Sonmez H, Tuncay E, Gokceoglu C. Models to predict the uniaxial compressive strength and the modulus of elasticity for Ankara agglomerate. Int J Rock Mech Min Sci. 2004;41(5):717-29. https://doi.org/10.1016/j.jirmms.2004.01.011.

Stober I, Bucher K. Enhanced-geothermal-systems, hot-dry-rock systems, deep-heat-mining. In: Geothermal energy. Berlin: Springer; 2013. https://doi.org/10.1007/978-3-642-13352-7_9.

Stueber AM, Saller AH, Ishida H. Origin, migration, and mixing of brines in the Permian Basin: geochemical evidence from the eastern Central Basin platform, Texas. AAPG Bull. 1998;82(9):1652-72.

Suarez-Rivera R, Stenebråten J, Dagrain F. Continuous scratch testing on core allows effective calibration of log-derived mechanical properties for use in sanding prediction evaluation. Soc Pet Eng. 2002. https://doi.org/10.2118/ 78157-MS.

Sygała A, Bukowska M, JanoszekT. High temperature versus geomechanical parameters of selected rocks - the present state of research. J Sustain Min. 2013;12(4):45-51. https://doi.org/10.7424/jsm130407.

Tang CM. Permian Basin. Encyclopædia Britannica. 2015. https://www.britannica.com/place/Permian-Basin.

Tesei T, Collettini C, Carpenter BM, Viti C, Marone C. Frictional strength and healing behavior of phyllosilicate-rich faults. J Geophys Res. 2012;117:B09402. https://doi.org/10.1029/2012JB009204.

Tham LG, Cheung YK, Tang CA. Numerical simulation of the failure process of rocks. Tamkang J Sci Eng. 2001;4:239-52.

Toth AN. Country update for Hungary. In: World Geothermal Congress, Reykjavik, Iceland. 2020.

Tullis J, Yund RA. Experimental deformation of dry Westerly granite. J Geophys Res. 1977;82(36):5705-18. https://doi.org/ 10.1029/JB082i036p05705

Ulm F-J, James S. The scratch test for strength and fracture toughness determination of oil well cements cured at high temperature and pressure. Cem Concr Res. 2011:41:942-6. https://doi.org/10.1016/i.cemconres.2011.04.014.

Wang X, Ghassemi A. A 3D thermal-poroelastic model for naturally fractured geothermal reservoir stimulation. American Rock Mechanics Association; 2012.

Wang F, Konietzky H, Herbst M. Influence of heterogeneity on thermo-mechanical behaviour of rocks. Comput Geotech. 2019. https://doi.org/10.1016/j.compgeo.2019.103184.

Wiemer S, Kraft T, Trutnevyte E, Roth P."Good practice" guide for managing induced seismicity in deep geothermal energy projects in Switzerland. SED, Swiss Seismological Service at ETH Zürich. 2017. https://doi.org/10.3929/ethzb-000254161.

Wong T-F. Effects of temperature and pressure on failure and post failure behaviour of Westerly granite. Mech Mater. 1982;1:13-7. https://doi.org/10.1016/0167-6636(82)90020-5

Wu G, Wang Y, Swift G, Chen J. Laboratory investigation of the effects of temperature on the mechanical properties of sandstone. Geotech Geol Eng. 2013;31:809-16. https://doi.org/10.1007/s10706-013-9614-x.

Wyering LD, Villeneuve MC, Wallis IC, Siratovich PA, Kennedy BM, Gravley DM, Cant JL. Mechanical and physical properties of hydrothermally altered rocks, Taupo Volcanic Zone, New Zealand. J Volcanol Geoth Res. 2014;288:76-93. 
Yao W, Xu Y, Xia K, et al. Dynamic mode II fracture toughness of rocks subjected to confining pressure. Rock Mech Rock Eng. 2020;53:569-86. https://doi.org/10.1007/s00603-019-01929-y.

Yılmaz I, Sendir H. Correlation of Schmidt hardness with unconfined compressive strength and Young's modulus in gypsum from Sivas (Turkey). Eng Geol. 2002;66:211-9. https://doi.org/10.1016/S0013-7952(02)00041-8.

Zbinden D, Rinaldi AP, Diehl T, Wiemer S. Hydromechanical modeling of fault reactivation in the St. Gallen deep geothermal project (Switzerland): poroelasticity or hydraulic connection? Geophys Res Lett. 2020. https://doi.org/10.1029/ 2019GL085201.

Zhang H, Huang Z, Zhang S, Yang Z, Mclennan JD. Improving heat extraction performance of an enhanced geothermal system utilizing cryogenic fracturing. Geothermics. 2020. https://doi.org/10.1016/j.geothermics.2020.101816.

Zhou Z, Jin Y, Zeng Y, Youn D. Experimental study of hydraulic fracturing in enhanced geothermal system. American Rock Mechanics Association; 2018.

Ziegler MO, Heidbach O. The 3D stress state from geomechanical-numerical modelling and its uncertainties: a case study in the Bavarian Molasse Basin. Geotherm Energy. 2020;8:11. https://doi.org/10.1186/s40517-020-00162-z.

Zoback MD. Reservoir geomechanics. New York: Cambridge University Press; 2010.

\section{Publisher's Note}

Springer Nature remains neutral with regard to jurisdictional claims in published maps and institutional affiliations.

\section{Submit your manuscript to a SpringerOpen ${ }^{\odot}$ journal and benefit from:}

- Convenient online submission

- Rigorous peer review

- Open access: articles freely available online

- High visibility within the field

- Retaining the copyright to your article

Submit your next manuscript at $\mathbf{s p r i n g e r o p e n . c o m ~}$ 